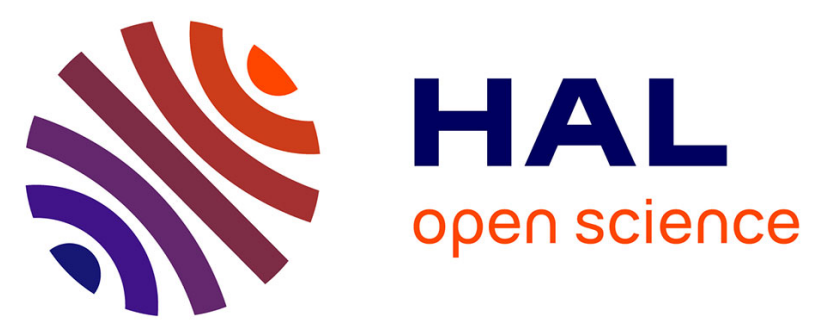

\title{
PLASMA OEA LEVEL IS CORRELATED WITH MUSCLE MASS AND MOBILITY IN OLD RATS.
}

Olivier Le Bacquer, J Salles, F Piscitelli, V Di Marzo, S Walrand

\section{To cite this version:}

Olivier Le Bacquer, J Salles, F Piscitelli, V Di Marzo, S Walrand. PLASMA OEA LEVEL IS CORRELATED WITH MUSCLE MASS AND MOBILITY IN OLD RATS.. European Society for Parenteral and Enteral Nutrition (ESPEN 2020), Sep 2020, Lyon, France. hal-03036273

\section{HAL Id: hal-03036273 \\ https://hal.inrae.fr/hal-03036273}

Submitted on 2 Dec 2020

HAL is a multi-disciplinary open access archive for the deposit and dissemination of scientific research documents, whether they are published or not. The documents may come from teaching and research institutions in France or abroad, or from public or private research centers.
L'archive ouverte pluridisciplinaire HAL, est destinée au dépôt et à la diffusion de documents scientifiques de niveau recherche, publiés ou non, émanant des établissements d'enseignement et de recherche français ou étrangers, des laboratoires publics ou privés. 


\section{ESPEN 2020 Abstract Submission}

\section{Topic: Nutritional assessment}

Abstract Submission Identifier: ESPEN20-ABS-1701

PLASMA OEA LEVEL IS CORRELATED WITH MUSCLE MASS AND MOBILITY IN OLD RATS.

O. Le Bacquer ${ }^{*}, \quad$, J. Salles ${ }^{1}$, F. Piscitelli ${ }^{2}$, V. Di Marzo ${ }^{2}$, S. Walrand ${ }^{1,3}$

${ }^{1}$ Unité de Nutrition Humaine, INRAE, Clermont-Ferrand cedex 1, France, ${ }^{2}$ Institute of Biomolecular Chemistry, National Research Council, Naples, Italy, ${ }^{3}$ Service de Nutrition Clinique, CHU Clermont-Ferrand, Clermont-Ferrand, France

If you think another topic than the one selected at first would suit your abstract, please choose below.: Carbohydrate and lipid metabolism

The presenting author fulfills the above conditions and wants to apply for a travel award: No The presenting author fulfills the above conditions and wants to apply for the ESPEN Prize: No

Rationale: Sarcopenia is an age-related loss of muscle mass and strength associated with changes in skeletal muscle protein homeostasis due to lipid accumulation and anabolic resistance. These two latter phenomena are also observed in obesity which is known to be associated with overactivated endocannabinoid system. The aim of this study was to evaluate the disturbances of the endocannabinoid system in ageing and their putative link to skeletal muscle mass and function in old rats.

Methods: 6-month adult and 24-month old male rats were used to evaluate locomotor activity in openfield and voluntary gait by Catwalk tests. Weight of the hindlimb muscles was measured after sacrifice, and plasma concentrations of endocannabinoid (AEA, 2AG) and endocannaiboid-like metabolites (PEA and OEA) were measured by LCF-MS/MS. Comparison between groups were analyzed by student t-test and Pearson's correlation analysis was used.

Results: Compared to adult rats, old rats display higher fat mass ( $19 \pm 1$ vs $14 \pm 1 \%, P<0.01)$ and lower lean mass $(72 \pm 2$ vs $80 \pm 2 \%, P<0.01)$, exemplified by a $49 \%$ decrease in hindlimb muscle mass $(P<0.01)$, characteristics of sarcopenia. This loss of muscle mass was associated with reduced traveled distance $(2720 \pm 550$ vs $4804 \pm 960 \mathrm{~cm}, P<0.01)$, mean speed $(12.8 \pm 1.8$ vs $10.1 \pm 0.8 \mathrm{~cm} / \mathrm{sec}, \mathrm{P}<0.01)$ and duration of activity $(268 \pm 49 \mathrm{vs} 374 \pm 50 \mathrm{sec}, \mathrm{P}<0.01)$ in openfield, and Catwalk analysis revealed that voluntary gait was severely impaired in old rats. Plasma levels of AEA, 2AG, PEA and OEA (pmol/ml) are described in the following table:

\begin{tabular}{|l|c|c|c|c|}
\hline & AEA & 2 AG & PEA & OEA \\
\hline Adult rats $(n=11)$ & $2.0 \pm 0.2$ & $48.9 \pm 6.2$ & $49.8 \pm 6.0$ & $21.4 \pm 2.6$ \\
\hline Old rats $(n=8)$ & $2.2 \pm 0.3$ & $64.6 \pm 8.3(P=0.07)$ & $37.1 \pm 2.6^{*}$ & $12.9 \pm 1.1^{* *}$ \\
\hline
\end{tabular}

${ }^{*} \mathrm{P}<0.05,{ }^{* *} \mathrm{P}<0,01$ vs adults.

Correlation analysis revealed that plasma levels of OEA, and to some extents PEA, were positively correlated with traveled distance $\left(r^{2}=0.31, P<0.02\right)$, mean speed $\left(r^{2}=0.20, P=0.06\right)$, duration of activity $\left(r^{2}=0.27, P<0.03\right)$ and several parameters of voluntary gait $(P<0.05)$.

Conclusion: These results demonstrate that plasma levels of endocannabinoids and endocannabinoid like metabolites are altered in sarcopenic old rats and that OEA plasma levels are associated with skeletal muscle dysfunction and loss of mobility with age.

\section{Disclosure of Interest: None Declared}

Keywords: endocannabinoids, sarcopenia 